\title{
Hipoglikemia u pacjentów poddanych chirurgii metabolicznej - przegląd literatury
}

Hypoglycaemia in patients undergoing metabolic surgery - a literature review

\author{
Katarzyna Szmygel1, Michał Hoffmann¹, Justyna Bigda², Łukasz Kaska², Monika Proczko-Stepaniak², Krzysztof Narkiewicz ${ }^{1}$ \\ ${ }^{1}$ Klinika Nadciśnienia Tętniczego i Diabetologii Gdańskiego Uniwersytetu Medycznego \\ ${ }^{2}$ Katedra i Klinika Chirurgii Ogólnej, Endokrynologicznej i Transplantacyjnej Gdańskiego Uniwersytetu Medycznego
}

\section{STRESZCZENIE}

Chirurgia bariatryczna jest obecnie najbardziej skuteczną metodą leczenia otyłości, niezależnie od zastosowanej metody, ponieważ w porównaniu z metodami niechirurgicznymi zapewnia większą redukcję masy ciała oraz kontrolę nad chorobami współtowarzyszącymi, przede wszystkim cukrzycą typu 2. Istotnym powikłaniem zabiegów chirurgii metabolicznej, zarówno u chorych na cukrzycę typu 2, jak i u osób bez cukrzycy, jest występowanie hipoglikemii - we wczesnej fazie pooperacyjnej najczęściej związanej z tak zwanym zespołem poposiłkowym, później (kilka miesięcy lub lat po operacji) spowodowanej endogennym hiperinsulinizmem (PBSH, hipoglikemia występująca po zabiegach bariatrycznych). Częstość występowania PBSH znacznie się waha, wynosząc 0,1-50\%, zależnie od przyjętych kryteriów. Patomechanizm tego zjawiska jest wieloczynnikowy i oparty między innymi na nieadekwatnym wydzielaniu inkretyn, w tym przede wszystkim glukagonopodobnego peptyd typu 1, w odpowiedzi na posiłek, zmodyfikowany metabolizm wątrobowy glukozy czy obniżenie stężenia greliny. W związku z brakiem dokładnej wiedzy na temat patofizjologii tego zjawiska brakuje jednoznacznych algorytmów leczenia. Niemniej można wyróżnić trzy opcje terapeutyczne: modyfikację diety, farmakoterapię i leczenie chirurgiczne.

\section{Choroby Serca i Naczyń 2019, 16 (4), 270-277}

Słowa kluczowe: hipoglikemia, chirurgia metaboliczna, bariatria

\section{ABSTRACT}

Bariatric surgery is currently the most effective method of obesity treatment, regardless of the method used. Compared to non-surgical methods, it ensures greater weight reduction and better control of comorbidities, especially type 2 diabetes. The complication of bariatric surgery, both with and without type 2 diabetes, is the presence of a significant decrease in blood glucose level - hypoglycaemia. In the early postoperative phase, it is mainly hypoglycaemia associated with the so-called 'dumping syndrome'. Later (months or years after the surgery), it is mainly caused by endogenous hyperinsulinism (PBSH, post-bariatric surgery hypoglycaemia). The incidence of PBSH varies considerably, from $0.1-50 \%$ depending on the adopted criteria. The pathomechanism of this phenomenon is multifactorial and based, among others, on inadequate incretins secretion, in particular glucagon-like

Adres do korespondencji: 
peptide 1, in response to a meal, modified hepatic glucose metabolism or reduction in ghrelin concentration. Due to incomplete understanding about the pathophysiology of this phenomenon, there are no treatment algorithms. Nevertheless, three therapeutic options can be distinguished:

\section{WPROWADZENIE}

Otyłość, według definicji Światowej Organizacji Zdrowia (WHO, World Health Organization) to nadmierne nagromadzenie tkanki tłuszczowej w organizmie przekraczające jego fizjologiczne potrzeby i możliwości adaptacyjne, które może prowadzić do skutków niekorzystnych dla zdrowia [1]. Najważniejszym i najbardziej rozpowszechnionym kryterium otyłości jest podwyższony wskaźnik masy ciała (BMI, body mass index) większy lub równy $30 \mathrm{~kg} / \mathrm{m}^{2}$ [2]. Równie ważnym narzędziem definiującym otyłość, zwłaszcza otyłość brzuszną/centralną, jest obwód pasa w centymetrach $-\mathrm{z}$ różnymi punktami odcięcia dla populacji w zależności od regionów świata. Dla Europejczyków kryteria otyłości brzusznej to obwód pasa u kobiet większy lub równy $80 \mathrm{~cm}$, a u mężczyzn większy lub równy $94 \mathrm{~cm}$ [2].

Do czynników ryzyka otyłości można zaliczyć czynniki genetyczne, dodatni wywiad rodzinny, nieodpowiednią dietę, brak lub zbyt mały wysiłek fizyczny, siedzący tryb życia, deprywację snu, czynniki socjoekonomiczne i czynniki mikrobiologiczne [2]. Według danych WHO w 2014 roku 1,9 miliarda osób w wieku powyżej 18 lat miało nadwagę, a u ponad 600 milionów rozpoznano otyłość. Liczba osób z nadwagą i otyłością się zwiększa, szczególnie w krajach rozwijających się o wschodzącej gospodarce. Prognozuje się, że w 2030 roku około 38\% światowej populacji osób dorosłych będzie miało nadwagę, a u kolejnych $20 \%$ zostanie rozpoznana otyłość.

Z otyłością współistnieje wiele chorób, między innymi cukrzyca typu 2, hiperlipidemia, choroby układu sercowo-naczyniowego, choroby układu oddechowego, choroby układu kostno-stawowego, choroba refluksowa przełyku, zaburzenia płodności, nietrzymanie moczu, zaburzenia psychiczne (przede wszystkim depresja endogenna). Ponadto obserwuje się wzrost zachorowalności na niektóre nowotwory, w tym nowotwór piersi, endometrium czy jelita grubego. Otyłość wpływa rów- diet modification, pharmacotherapy, and surgical treatment.

Choroby Serca i Naczyń 2019, 16 (4), 270-277

Key words: hypoglycemia, metabolic surgery, bariatric surgery

nież negatywnie na jakość życia, a oczekiwana długość życia osób z nadwagą lub otyłością jest o 4-7 lat krótsza [2]. Koszty leczenia otyłości oraz związanych z nią chorób są ogromne [3]. Szacuje się, że na świecie koszty te wynoszą 0,7-2,8\% wydatków państw na opiekę zdrowotną. Dlatego tak istotne są skuteczne metody leczenia otyłości i związanych z nią chorób [4]. Sama modyfikacja stylu życia może prowadzić do zmniejszenia masy ciała o 5-10\%, jednakże po 3-6 miesiącach u większości osób występuje ponowne zwiększenie masy ciała, a osiągana masa u ponad $90 \%$ osób jest co najmniej równa masie ciała sprzed interwencji [5].

W porównaniu z metodami niechirurgicznymi chirurgia bariatryczna zapewnia większą redukcję masy ciała, a efekt zmniejszenia masy ciała utrzymuje się co najmniej 15-20 lat [6]. Ponadto operacyjne leczenie otyłości zapewnia kontrolę nad chorobami współtowarzyszącymi, przede wszystkim cukrzycą typu 2. Dlatego chirurgia metaboliczna, niezależnie od zastosowanej metody, jest obecnie najbardziej skuteczną metodą leczenia otyłości [7]. Do zabiegu są kwalifikowani dorośli pacjenci: 1) z BMI większym lub równym $40 \mathrm{~kg} / \mathrm{m}^{2}$, 2) z BMI większym lub równym $35 \mathrm{~kg} / \mathrm{m}^{2}$ i chorobami wspólistniejącymi, na przykład cukrzycą typu 2, nadciśnieniem tętniczym, hiperlipidemią. Ponadto Amerykańskie Towarzystwo Diabetologiczne (ADA, American Diabetes Association) zaleca rozważenie zabiegu u pacjentów z BMI $30-34 \mathrm{~kg} /$ $/ \mathrm{m}^{2}$ i źle kontrolowaną cukrzycą typu 2 mimo stosowania optymalnego leczenia farmakologicznego [8]. Liczba pacjentów poddawanych zabiegom chirurgii metabolicznej zwiększa się z roku na rok - w 2013 roku na świecie wykonano 468609 zabiegów [7]. Do najczęściej wykonywanych procedur zalicza się wyłączenie żołądkowe typu Roux-en-Y (RYGB, Roux-en-Y gastric bypass) oraz rękawową resekcję żołądka (SG, sleeve gastrectomy). Zabieg wyłączenia żołądkowego typu Roux-en-Y polega na wytworzeniu zbiornika o objętości 15-20 ml w okolicy podwpustowej 
żołądka. Następnie zbiornik ten zespala się z wydzieloną pętlą jelita cienkiego, co pozwala na wyłączenie z pasażu pokarmu $60-100 \mathrm{~cm}$ przewodu pokarmowego (pozostałą część żołądka, dwunastnicę, początkowy odcinek jelita czczego). Połączenie ominiętego odcinka z przewodem pokarmowym znajduje się około $100 \mathrm{~cm}$ od miejsca zespolenia wytworzonego zbiornika z pętlą jelita cienkiego. Z kolei zabieg SG polega na resekcji do $85 \%$ powiększonego żołądka. Rezultatem jest zmniejszenie jego objętości do $150 \mathrm{ml}$.

\section{CHIRURGIA BARIATRYCZNA A REMISJA CUKRZYCY TYPU 2}

Chirurgia metaboliczna przynosi nie tylko poprawę kontroli glikemii u otyłych i nieotyłych chorych na cukrzycę typu 2, ale także całkowitą remisję cukrzycy typu 2 w tej grupie pacjentów. Odsetek osób poddanych operacji bariatrycznej, u których obserwowano remisję cukrzycy typu 2, waha się od 0 do ponad $90 \%$ [9]. Według metaanalizy przeprowadzonej przez Buchwald i wsp. [10] poprawa kontroli glikemii lub remisja cukrzycy wystąpiła u 86,6\% pacjentów. Z kolei według danych Rao i wsp. [11] 65-93\% pacjentów spełniało kryteria remisji, a u Panuzi i wsp. [12] - 27\%. Natomiast według najnowszej metaanalizy Rubio-Almanza i wsp. [9] odsetek ten wynosi 43\%. Różnice te wynikają przede wszystkim z przyjęcia różnych kryteriów wystąpienia remisji cukrzycy — od kryterium nieprzyjmowania leków przeciwcukrzycowych do kryteriów laboratoryjnych, takich jak podwyższone glikemie na czczo i poposiłkowe, stężenie hemoglobiny glikowanej [13-15]. Obecnie zarówno ADA, jak i Międzynarodowa Federacja Diabetologiczna (IDF, International Diabetes Federation) określiły kryteria remisji cukrzycy u pacjentów poddanych zabiegom chirurgii metabolicznej. Według ADA częściowa remisja występuje wtedy, gdy glikemia na czczo mieści się w zakresie 100-125 mg/dl i stężenie hemoglobiny glikowanej nie przekracza 6,5\%, natomiast całkowita remisja, gdy glikemia na czczo wynosi poniżej $100 \mathrm{mg} / \mathrm{dl}$, a odsetek hemoglobiny glikowanej poniżej $5,6 \%$ [16]. Dodatkowo w obu przypadkach musi być również spełnione kryterium czasowe, tj. co najmniej 12 miesięcy bez leczenia przeciwcukrzycowego. Na różnice odsetka remisji cukrzycy typu 2 po zabiegach bariatrycznych wpływa również rodzaj zabiegu, któremu poddano pacjentów. Według Buchwald i wsp. [10] największy odsetek remisji występował u pacjentów poddanych operacji wyłączenia żółciowo-trzustkowego z ominięciem dwunastnicy (95,1\%), następnie - odpowiednio-RYGB
$(80,3 \%)$, SG $(79,7 \%)$ i założeniu regulowanej opaski żołądkowej $(56,7 \%)$. Ponadto różnice wyników mogą się wiązać z długością pooperacyjnego okresu obserwacji pacjentów.

Według danych z literatury oraz obserwacji klinicznych remisja lub poprawa kontroli glikemii u otyłych i nieotyłych chorych na cukrzycę typu 2 występuje w ciągu kilku dni do kilku tygodni po operacji bariatrycznej [17-19]. Według badania przeprowadzonego przez Schauer i wsp. [20] u 30\% otyłych chorych na cukrzycę typu 2 poddanych zabiegowi RYGB remisja wystąpiła średnio w ciągu 2,8 dnia po zabiegu. Co istotne, u 50\% pacjentów poddanych zabiegowi chirurgii metabolicznej efekt ten utrzymuje się ponad 5 lat [21]. U pozostałych następuje nawrót choroby. Mechanizmy remisji cukrzycy u chorych poddanych operacji bariatrycznej nie są do końca poznane, niemniej wydaje się, że nie zależą od zmniejszenia masy ciała. Pod uwage jest branych kilka hipotez, między innymi: zmiana stężenia i działania hormonów jelitowych (przede wszystkim hormonów osi inkretynowej, greliny, cholecystokininy, peptydu YY), zmiana stężenia kwasów żółciowych działających w wątrobie poprzez stymulację receptora farnezoidowego $X$ (FXR, farnesoid X receptor) oraz TGR5 (G-protein-coupled bile acid receptor, Gpbar1) i w ten sposób wpływających na metabolizm glukozy i lipidów [22, 23], zmiana modulacji nerwowej (oś mózg-jelita-wątroba), wzrost stężeń fibroblastycznych czynników wzrostu 19 i 21 (FGF [fibroblast growth factor]-19, -21) czy zmiany w mikrobiocie jelitowej. W rezultacie dochodzi do osłabienia insulinooporności oraz zmniejszenia wątrobowej produkcji glukozy. Ponadto następują poprawa funkcji komórek beta wysp trzustkowych, zwiększenie wydzielania insuliny i zwiększenie wykorzystania glukozy. Skutkiem tego, oprócz remisji lub poprawy kontroli glikemii u chorych na cukrzycę typu 2, jest również występowanie hipoglikemii u pacjentów po zabiegu bariatrycznym. Najczęściej po operacjach RYGB iSG.

\section{HIPOGLIKEMIA}

\section{Definicja, podzial i częstość występowania}

Hipoglikemia jest definiowana jako występowanie objawów klinicznych (neurowegetatywnych lub neuroglikopenicznych) z jednocześnie niskim stężeniem glukozy we krwi (w zależności od autora i przyjętych kryteriów stężenie glukozy < 50-70 mg/dl) oraz ustąpieniem objawów po wzroście stężenia glukozy we krwi 
(triada Whipple'a). Objawy neurowegetatywne pojawiają się przy glikemii poniżej $60 \mathrm{mg} / \mathrm{dl}$ i zalicza się do nich między innymi: niepokój, drażliwość, nerwowość, osłabienie, wzmożoną potliwość, poszerzenie źrenic, bladość powłok. Natomiast do objawów neuroglikopenicznych, które pojawiają się przy stężeniu glukozy we krwi poniżej $50 \mathrm{mg} / \mathrm{dl}$, zalicza się: zaburzenia orientacji, mowy i koordynacji ruchów, splątanie, trudności kojarzenia i myślenia, drgawki, śpiączkę.

Hipoglikemia występująca we wczesnej fazie po zabiegu (do roku) jest związana z tak zwanym zespołem poposiłkowym. Jest on skutkiem zbyt szybkiego przechodzenia hiperosmolalnej treści żołądkowej do jelita cienkiego. Objawy, takie jak: bóle brzucha, nudności, wymioty, biegunka, osłabienie, tachykardia, spadek ciśnienia tętniczego krwi, zaczerwienienie twarzy, zawroty głowy, typowo pojawiają się kilkanaście, kilkadziesiąt minut po posiłku, zwłaszcza bogatym w węglowodany proste (tzw. wczesny zespół poposiłkowy). W późniejszym okresie, 1-3 godzin po posiłku, występuje hipoglikemia (tzw. późny zespół poposiłkowy). Jest ona rezultatem szybkiego i nieadekwatnego wzrostu stężenia insuliny w odpowiedzi na wzrost glikemii związany z szybkim wchłanianiem węglowodanów prostych w początkowym odcinku jelita cienkiego. Skuteczną metodą leczenia w tym wypadku jest modyfikacja diety, polegająca przede wszystkim stosowaniu diety o niskim indeksie glikemicznym.

Hipoglikemia (PBSH) spowodowana endogennym hiperinsulinizmem ujawnia się z kolei po kilku miesiącach lub latach po operacji bariatrycznej, najczęściej po wyłączeniu żołądkowym typu Roux-en-Y — według danych z literatury czas ten wynosi od 1 do 5 lat. Dane dotyczące częstości występowania PBSH są sprzeczne. Według Marsk i wsp. [24] oraz Kellogg i wsp. [25] częstość występowania ciężkiej hipoglikemii z objawami neurologicznymi u pacjentów po operacjach bariatrycznych wynosiła odpowiednio mniej niż 0,2\% i 0,36\%. Również według amerykańskiego badania na podstawie danych z bazy BOLD częstość występowania ciężkich hipoglikemii po RYGB była niższa niż 0,1\% [26]. Badania te nie były jednak w pełni reprezentatywne: do badania Marsk i wsp. [24] włączono wyłącznie pacjentów z ciężką hipoglikemią, z kolei badanie Kellog i wsp. [25] było jednoośrodkowe, a baza BOLD zawierała przypadki hipoglikemii samodzielnie zgłaszanych przez pacjenta bez obiektywizacji w badaniach laboratoryjnych. Częstość występowania ciężkiej hipoglikemii w innych badaniach wynosiła 11,6\% [27]. Z kolei częstość występowania łagodnej i umiarkowanej hipoglikemii jest znacznie wyższa — bezobjawowa hipoglikemia może dotyczyć 30-50\% pacjentów po operacjach bariatrycznych [27, 28].

Kryteria rozpoznania PBSH również nie są ściśle określone, co ma wpływ na opisywane powyżej różnice w częstości występowania tego zjawiska. Hipoglikemia występująca po zabiegach bariatrycznych definiowana jest jako: 1) występowanie objawów klinicznych z jednocześnie niskim stężeniem glukozy we krwi (zależnie od autorów < 50-55 mg/l) oraz ustąpieniem objawów po wzroście stężenia glukozy we krwi (triada Whipple'a) [29], 2) występowanie poposiłkowej hipoglikemii z towarzyszącymi objawami neuroglikopenicznymi co najmniej rok po operacji [25],3) wystąpienie objawów hipoglikemii po mieszanym posiłku bogatym w węglowodany i brak wystąpienia objawów po mieszanym posiłku z niską zawartością węglowodanów [25].

W związku z brakiem precyzyjnej definicji również metody diagnostyczne nie są ściśle zdefiniowane. W przeszłości głównym testem stosowanym do rozpoznania PBSH był doustny test obciążenia glukozą (z różnym stosowanym obciążeniem: 30-100 g glukozy). Obecnie nie jest już jednak rekomendowany z kilku względów. Po pierwsze zaobserwowano, że u 10\% zdrowych osób wynik testu jest dodatni [30], a więc u pacjentów pobariatrycznych mogłoby to również utrudniać właściwą interpretację badania. Ponadto duży ładunek hiperosmolalny może powodować objawy zespołu poposiłkowego, które mogą być mylone z objawami PBSH [31]. Do innych aktualnie stosowanych metod zalicza się stosowanie testów z mieszanym białkowo-tłuszczowo-węglowodanowym posiłkiem - niestety tu również brakuje standaryzacji. Od niedawna w diagnostyce PBSH stosowane są również ciągłe systemy monitorowania glikemii (CGMS), dające możliwość pełnego wglądu w glikemie danego pacjenta. Jednakże metoda ta również ma swoje ograniczenia stężenie glukozy jest mierzone w tkance podskórnej, a nie we krwi. Dokładność urządzenia w określaniu wartości glukozy we krwi w czasie hipoglikemii jest niska [32,33] — dokładność może być uzyskana zaledwie w 60-73\% próbek w zakresie glikemii $40-80 \mathrm{mg} / \mathrm{dl}$ [21, 22]. Ponadto urządzenia te mają dość wysoką cenę. Oczywiście idealną metodą diagnostyczną PBSH byłby pomiar stężeń glukozy i insuliny we krwi żylnej w momencie wystąpienia objawów sugerujących spadek glikemii [34], jednak w zdecydowanej większości przypadków jest to po prostu niemożliwe. 
W trakcie diagnostyki PBSH należy pamiętać również o innych możliwych przyczynach hipoglikemii i w związku z tym przeprowadzeniu odpowiedniej diagnostyki różnicowej.

\section{Mechanizm powstawania}

Od momentu opisania przez Service i wsp. w 2005 roku [35] serii 6 przypadków hiperinsulinemicznej hipoglikemii spowodowanej przerostem komórek beta wysp trzustkowych w przebiegu nesidoblastozy powstało wiele koncepcji patofizjologicznego mechanizmu występowania hipoglikemii u pacjentów poddanych zabiegom chirurgii metabolicznej. Sugerowany wówczas przez autorów związek hipoglikemii ze zwiększoną masą komórek beta wysp trzustkowych nie został potwierdzony w innych badaniach.

Obecnie do najbardziej aktualnych teorii powstawania PBSH należy teoria dotycząca nieadekwatnego wydzielania inkretyn, w szczególności glukozozależnego peptydu insulinotropowego (GIP, glucose-dependent insulinotropic peptide) i glukagonopodobnego peptydu 1 (GLP-1, glucagon-like peptide 1), w odpowiedzi na posiłek. Potwierdzono to między innymi w badaniu Goldfine i wsp. [36]. Szybki pasaż składników pokarmowych przez zmieniony operacyjnie przewód pokarmowy powoduje szybki wzrost stężenia glukozy we krwi. Wykazali to Salehi i wsp. [37], wykorzystując w swoich badaniach nad wchłanianiem glukozy u pacjentów po operacjach bariatryczych znakowaną glukozę. Ten szybki wzrost glikemii w konsekwencji stymuluje komórki L jelita cienkiego do nadmiernego wydzielania GLP-1 [36, 38, 39]. Poprzez łączenie się z receptorami na komórkach beta wysp trzustkowych GLP-1 stymuluje trzustkę do produkcji zbyt dużej ilości insuliny (przełamując? glukozozależny efekt działania inkrety), a poprzez łączenie się z komórkami alfa — hamuje uwalnianie glukagonu [36]. Prowadzi to $w$ rezultacie do spadku stężenia glukozy we krwi. Tę istotną rolę GLP-1 w mechanizmie powstawania $\mathrm{PBSH}$ u pacjentów poddanych chirurgii metabolicznej potwierdzili Salehi i wsp. [37] — chorzy z objawami i bez objawów hipoglikemii zostali poddani testowi z mieszanym białkowo-tłuszczowo-węglowodanowym posiłkiem, jednoczasowo zastosowano ciągły wlew soli fizjologicznej albo antagonisty receptora GLP-1 (exendin-9). Zablokowanie receptorów GLP-1 przez ich antagonistę (exendin-9) spowodowało ustąpienie objawów hipoglikemii oraz wyrównanie wartości glukozy we krwi. Jednak w innym badaniu Abrahamsson i wsp. [40] opisali
5 przypadków ustąipienia hipoglikemii po stosowaniu liraglutydu — analogu GLP-1. Zatem rola inrektyn jest niewątpliwie istotna w mechanizmie powstawania PBSH, niemniej ciągle nie jest ona jednoznacznie wyjaśniona.

Przyczynami wystąpienia u pacjentów po operacjach bariatrycznym PBSH mogą być również zmniejszone stężenie greliny [41], zmodyfikowany metabolizm wątrobowy glukozy, zaburzenia mikrobioty jelitowej czy stężenia kwasów tłuszczowych [42, 43]. Podsumowując, mechanizm PBSH jest złożony i wieloczynnikowy. Konieczne jest zatem prowadzenie dalszych badań nad poznaniem przyczyn występowania tego zjawiska.

\section{Leczenie}

W związku z brakiem jasno określonych kryteriów rozpoznania PBSH oraz brakiem dokładnej wiedzy na temat patofizjologii tego zjawiska brakuje jednoznacznych algorytmów leczenia PBSH. Niemniej, opierając się na dotychczas przeprowadzonych badaniach (będących raczej opisami przypadków niż dużymi randomizowanymi badaniami), można wyróżnić 3 opcje terapeutyczne: 1) modyfikację diety, 2) leczenie farmakologiczne, 3) leczenie chirurgiczne.

\section{Modyfikacja diety}

Pierwszym krokiem w leczeniu PBSH jest modyfikacja diety, która polega przede wszystkim na ograniczeniu przyjmowanych węglowodanów prostych, na spożywaniu produktów o niskim indeksie glikeminicznym, bogatych w błonnik, na spożywaniu produktów węglowodanowych razem z produktami tłuszczowo-białkowymi. Ponadto sugeruje się jedzenie 5-6 mniejszych posiłków dziennie oraz opóźnienie przyjmowania płynów o około 30 minut w stosunku do posiłków stałych. Niektórzy rekomendują również leżenie przez około 30 minut po posiłku.

W dotychczas przeprowadzonych badaniach między innymi przez Kellog i wsp. [25], Meijeren i wsp. [44] czy Bentle i wsp. [45] udowodniono, że stosowanie diety z ograniczeniem, a nawet wykluczeniem węglowodanów powodowało zmniejszenie częstości występowania hipoglikemii w grupie pacjentów pobariatrycznych z PBSH. Niemniej jednak utrzymanie tak restrykcyjnej diety jest trudne.

\section{Farmakoterapia}

Kolejną opcją terapeutyczną jest leczenie farmakologiczne. Dotychczas w leczeniu PBSH stosowano akarbozę 
w dawkach 25-100 mg 3 razy dziennie. Jako inhibitor alfa-glukozydazy akarboza powoduje wolniejsze wchłanianie węglowodanów w przewodzie pokarmowym, a tym samym spowalnia poposiłkowy wzrost stężenia glukozy we krwi. Ponadto, jak udowodnili Valderas i wsp. [46], redukuje również wydzielanie insuliny i GLP-1. Jednak nie u wszystkich pacjentów lek jest skuteczny, a dodatkowo występują niepożądane objawy ze strony przewodu pokarmowego, takie jak wzdęcia, biegunki.

W kilku przypadkach PBSH opisano również terapię antagonistą wapnia - werapamilem stosowanym między innymi w leczeniu guza insulinowego. Niemniej wyniki badań są niespójne $[47,48]$, a często występujące działania niepożądane (spadek ciśnienia tętniczego, obrzęki kończyn dolnych) stanowią istotne ograniczenie w powszechnym użyciu tego leku.

Terapia analogami somatostatyny (oktreotydem, pasyreotydem, lanreotydem), powszechnie stosowana w leczeniu guzów neuroendokrynnych, zwalniająca pasaż pokarmu w przewodzie pokarmowym i zmniejszająca wydzielanie insuliny oraz GLP-1, była opisana w kilku artykułach w leczeniu PBSH. Myint i wsp. [49] w swoim badaniu opisali długoterminowe (4 lata) ustąpienie hipoglikemii przy terapii lanreotydem. Jednak również terapia analogami somatostatyny ma swoje ograniczenia - wysokie koszty, poddawanie pacjentów comiesięcznym głębokim iniekcjom domięśniowym, ryzyko wystąpienia działań niepożądanych ze strony leku, takich jak: biegunki, wydłużenie odstępu QT, kamica pęcherzyka żółciowego.

Kolejnym lekiem stosowany w leczeniu PBSH jest diazoksyd, który poprzez blokowanie ATP-zależnego kanału potasowego w komórkach beta trzustki zmniejsza wydzielanie insuliny $[50,51]$. Jednak ze względu na działania niepożądane (spadek ciśnienia tętniczego, bóle głowy, retencja płynów, obrzęki kończyn dolnych) jego wykorzystanie również jest ograniczone.

Abrahamsson i wsp. [40] opisali ponadto zastosowanie analogu GLP-1 (liraglutydu) w 5 przypadkach PBSH.

Trwają badania kliniczne nad kolejnymi metodami i lekami, które można by zastosować w leczeniu PBSH. Należą do nich między innymi exendin-9 — antagonista GLP-1,XOMA 358 - ludzkie monoklonalne przeciwciało czy zastosowanie podskórnego wlewu glukagonu.

\section{Leczenie chirurgiczne}

Obecnie do najczęściej stosowanych opcji leczenia PBSH zalicza się: 1) wykonanie gastrostomii do pozosta- łej części żołądka, 2) odwrócenie zabiegu. Początkowo stosowana częściowa lub całkowita pankreatektomia nie jest już zalecana.

\section{PODSUMOWANIE}

Hipoglikemia u pacjentów poddawanych chirurgii metabolicznej jest istotnym powikłaniem operacji. W związku ze wzrostem liczby wykonywanych zabiegów liczba pacjentów z PBSH będzie większa, dlatego tak istotne są dalsze badania nad patofizjologicznymi mechanizmami powstawania tego zjawiska oraz poszukiwanie nowych opcji terapeutycznych.

\section{KONFLIKT INTERESÓW}

Autorzy nie zgłaszają konfliktu interesów.

\section{PIŚMIENNICTWO}

1. Obesity: preventing and managing the global epidemic. Report of a WHO consultation. World Health Organ Tech Rep Ser. 2000; 894(i-xii): 1-253, indexed in Pubmed: 11234459.

2. Hruby A, Hu F. The epidemiology of obesity: a big picture. PharmacoEconomics. 2014; 33(7): 673-689, doi: 10.1007/s40273-014-0243-x, indexed in Pubmed: 25471927.

3. Cawley J, Meyerhoefer C. The medical care costs of obesity: an instrumental variables approach. J Health Econ. 2012; 31(1): 219-230.

4. Withrow D, Alter DA. The economic burden of obesity worldwide: a systematic review of the direct costs of obesity. Obes Rev. 2011; 12(2): 131-141, doi: 10.1111/j.1467-789x.2009.00712.x, indexed in Pubmed: 20122135

5. Franz MJ, VanWormer JJ, Crain AL, et al. Weight-loss outcomes: a systematic review and meta-analysis of weight-loss clinical trials with a minimum 1-year follow-up. J Am Diet Assoc. 2007; 107(10): 1755-1767, doi: 10.1016/j.jada.2007.07.017, indexed in Pubmed: 17904936.

6. Sjöström L. Review of the key results from the Swedish Obese Subjects (SOS) trial - a prospective controlled intervention study of bariatric surgery. J Intern Med. 2013; 273(3): 219-234, doi: 10.1111/joim.12012, indexed in Pubmed: 23163728.

7. Colquitt JL, Pickett K, Loveman E, et al. Surgery for weight loss in adults. Cochrane Database Syst Rev. 2014, doi: 10.1002/14651858. cd003641. pub4, indexed in Pubmed: 25105982.

8. Marathe PH, Gao HX, Close KL. American Diabetes Association standards of medical care in diabetes 2017. J Diabetes. 2017; 9(4): 320-324, doi: 10.1111/1753-0407.12524, indexed in Pubmed: 28070960.

9. Rubio-Almanza M, Hervás-Marín D, Cámara-Gómez R, et al. Does metabolic surgery lead to diabetes remission in patients with $\mathrm{BMI}<30 \mathrm{~kg} / \mathrm{m} 2$ ?: a meta-analysis. Obes Surg. 2019; 29(4): 1105-1116, doi: 10.1007/s11695-018-03654-x, indexed in Pubmed: 30604080

10. Buchwald $H$, Estok R, Fahrbach $\mathrm{K}$, et al. Weight and type 2 diabetes after bariatric surgery: systematic review and meta-analysis. Am J Med. 2009; 122(3): 248-256.e5, doi: 10.1016/j.amjmed.2008.09.041, indexed in Pubmed: 19272486.

11. Rao WS, Shan CX, Zhang W, et al. A meta-analysis of short-term outcomes of patients with type 2 diabetes mellitus and $\mathrm{BMI} \leq 35 \mathrm{~kg} / \mathrm{m} 2 \mathrm{un}$ dergoing Roux-en-Y gastric bypass. World J Surg. 2014; 39(1): 223-230, doi: 10.1007/s00268-014-2751-4, indexed in Pubmed: 25159119.

12. Panunzi S, Gaetano ADe, Carnicelli A, et al. Predictors of remission of diabetes mellitus in severely obese individuals 
undergoing bariatric surgery. Ann Surg. 2015; 261(3): 459-467 doi: 10.1097/sla.0000000000000863, indexed in Pubmed: 25361217.

13. García-Caballero M, Valle M, Martínez-Moreno JM, et al. Resolution of diabetes mellitus and metabolic syndrome in normal weight 24$-29 \mathrm{BMI}$ patients with one anastomosis gastric bypass. Nutr Hosp. 2012; 27(2): 623-631, doi: 10.1590/S0212-16112012000200041, indexed in Pubmed: 22732993.

14. Wentworth JM, Playfair J, Laurie C, et al. Multidisciplinary diabetes care with and without bariatric surgery in overweight people: a randomised controlled trial. Lancet Diabetes Endocrinol. 2014; 2(7): 545-552, doi: 10.1016/s2213-8587(14)70066-x, indexed in Pubmed: 24731535.

15. Cui JF, Chen T, Shi L, et al. Gastric bypass surgery in non-obese patients with type 2 diabetes mellitus: a 1-year follow-up of 58 cases in Chinese. Int J Clin Exp Med. 2015; 8(3): 4393-4398, indexed in Pubmed: 26064359

16. Buse JB, Caprio S, Cefalu WT, et al. How do we define cure of diabetes? Diabetes Care. 2009; 32(11): 2133-2135, doi: 10.2337/dc099036, indexed in Pubmed: 19875608

17. Pories WJ, Mehaffey JH, Staton KM. The surgical treatment of type two diabetes mellitus. Surg Clin North Am. 2011; 91(4): 821-836 doi: 10.1016/j.suc.2011.04.008, indexed in Pubmed: 21787970.

18. Cefalu WT, Bray GA, Home PD, et al. Advances in the science, treatment, and prevention of the disease of obesity: reflections from a Editors' Expert Forum. Diabetes Care. 2015; 38(8): 1567-1582, doi: 10.2337/dc15-1081, indexed in Pubmed: 26421334.

19. Ashrafian H, Athanasiou T, Li JV, et al. Diabetes resolution and hyperinsulinaemia after metabolic Roux-en-Y gastric bypass. Obes Rev. 2011; 12(5): e257-e272, doi: 10.1111/j.1467-789x.2010.00802.x, indexed in Pubmed: 20880129

20. Schauer PR, Burguera B, Ikramuddin S, et al. Effect of laparoscopic Roux-en Y gastric bypass on type 2 diabetes mellitus. Ann Surg. 2003; 238(4): 467-484, doi: 10.1097/01.sla.0000089851.41115.1b, indexed in Pubmed: 14530719

21. Mingrone G, Panunzi S, Gaetano ADe, et al. Bariatric-metabolic surgery versus conventional medical treatment in obese patients with type 2 diabetes: 5 year follow-up of an open-label, single-centre, randomised controlled trial. The Lancet. 2015; 386(9997): 964-973, doi: 10.1016/s0140-6736(15)00075-6, indexed in Pubmed: 26369473.

22. Prawitt J, Abdelkarim M, Stroeve JHM, et al. Farnesoid X receptor deficiency improves glucose homeostasis in mouse models of obesity. Diabetes. 2011; 60(7): 1861-1871, doi: 10.2337/db11-0030, indexed in Pubmed: 21593203

23. Thomas C, Gioiello A, Noriega L, et al. TGR5-mediated bile acid sensing controls glucose homeostasis. Cell Metab. 2009; 10(3): 167-177, doi: 10.1016/j.cmet.2009.08.001, indexed in Pubmed: 19723493.

24. Marsk R, Jonas E, Rasmussen F, et al. Nationwide cohort study of post-gastric bypass hypoglycaemia including 5,040 patients undergoing surgery for obesity in 1986-2006 in Sweden. Diabetologia. 2010; 53(11): 2307-2311, doi: 10.1007/s00125-010-1798-5, indexed in Pubmed: 20495972

25. Kellogg TA, Bantle J, Leslie D, et al. Postgastric bypass hyperinsulinemic hypoglycemia syndrome: characterization and response to a modified diet. Surg Obes Relat Dis. 2008; 4(4): 492-499, doi: 10.1016/j. soard.2008.05.005, indexed in Pubmed: 18656831.

26. Sarwar H, Chapman W, Pender J, et al. Hypoglycemia after Roux-en-Y gastric bypass: the BOLD experience. Obes Surg. 2014; 24(7): 1120-1124, doi: 10.1007/s11695-014-1260-8, indexed in Pubmed: 24737312.

27. Lee CJ, Clark JM, Schweitzer M, et al. Prevalence of and risk factors for hypoglycemic symptoms after gastric bypass and sleeve gastrectomy. Obesity. 2015; 23(5): 1079-1084, doi: 10.1002/oby.21042, indexed in Pubmed: 25866150

28. Papamargaritis D, Koukoulis G, Sioka E, et al. Dumping symptoms and incidence of hypoglycaemia after provocation test at 6 and
12 months after laparoscopic sleeve gastrectomy. Obes Surg. 2012; 22(10): 1600-1606, doi: 10.1007/s11695-012-0711-3, indexed in Pubmed: 22773085

29. Vella A, Service F. Incretin hypersecretion in post-gastric bypass hypoglycemia - primary problem or red herring? J Clin Endocrinol Metab. 2007; 92(12): 4563-4565, doi: 10.1210/jc.2007-2260, indexed in Pubmed: 18056781.

30. Lev-Ran A, Anderson RW. The diagnosis of postprandial hypoglycemia. Diabetes. 1981; 30(12): 996-999, doi: 10.2337/diab.30.12.996, indexed in Pubmed: 7308588.

31. Tack J, Arts J, Caenepeel P, et al. Pathophysiology, diagnosis and management of postoperative dumping syndrome. Nat Rev Gastroenterol Hepatol. 2009; 6(10): 583-590, doi: 10.1038/nrgastro.2009.148, indexed in Pubmed: 9724252

32. Parkes JL, Slatin SL, Pardo S, et al. A new consensus error grid to evaluate the clinical significance of inaccuracies in the measurement of blood glucose. Diabetes Care. 2000; 23(8): 1143-1148, doi: 10.2337/diacare.23.8.1143, indexed in Pubmed: 10937512.

33. Clarke WL, Cox D, Gonder-Frederick LA, et al. Evaluating clinical accuracy of systems for self-monitoring of blood glucose. Diabetes Care. 1987; 10(5): 622-628, doi: 10.2337/diacare.10.5.622, indexed in Pubmed: 3677983

34. Vilarrasa N, Goday A, Rubio M, et al. Hyperinsulinemic hypoglycemia after bariatric surgery: diagnosis and management experience from a Spanish Multicenter Registry. Obes Facts. 2016; 9(1): 41-51, doi: 10.1159/000442764, indexed in Pubmed: 26901345

35. Service GJ, Thompson GB, Service FJ, et al. Hyperinsulinemic hypoglycemia with nesidioblastosis after gastric-bypass surgery. N Engl J Med. 2005; 353(3): 249-254, doi: 10.1056/nejmoa043690, indexed in Pubmed: 16034010.

36. Goldfine AB, Mun EC, Devine E, et al. Patients with neuroglycopenia after gastric bypass surgery have exaggerated incretin and insulin secretory responses to a mixed meal. J Clin Endocrinol Metab. 2007; 92(12): 4678-4685, doi: 10.1210/jc.2007-0918, indexed in Pubmed: 17895322

37. Salehi M, Gastaldelli A, D'Alessio D. Blockade of glucagon-like peptide 1 receptor corrects postprandial hypoglycemia after gastric bypass. Gastroenterology. 2014; 146(3): 669-680.e2, doi: 10.1053/j. gastro.2013.11.044, indexed in Pubmed: 24315990.

38. Rabiee A, Magruder J, Salas-Carrillo R, et al. Hyperinsulinemic hypoglycemia after Roux-en-Y gastric bypass: unraveling the role of gut hormonal and pancreatic endocrine dysfunction. J Surg Res. 2011; 167(2): 199-205, doi: 10.1016/j.jss.2010.09.047, indexed in Pubmed: 21414635.

39. Salehi M, Prigeon RL, D'Alessio DA. Gastric bypass surgery enhances glucagon-like peptide 1-stimulated postprandial insulin secretion in humans. Diabetes. 2011; 60(9): 2308-2314, doi: 10.2337/db11-0203, indexed in Pubmed: 21868791.

40. Abrahamsson N, Engström B, Sundbom M, et al. GLP1 analogs as treatment of postprandial hypoglycemia following gastric bypass surgery: a potential new indication? Eur J Endocrinol. 2013; 169(6): 885-889, doi: 10.1530/eje-13-0504, indexed in Pubmed: 24086087.

41. Cummings DE, Weigle DS, Frayo RS, et al. Plasma ghrelin levels after diet-induced weight loss or gastric bypass surgery. N Engl J Med. 2002; 346(21): 1623-1630, doi: 10.1056/nejmoa012908, indexed in Pubmed: 12023994

42. Liou AP, Paziuk M, Luevano JM, et al. Conserved shifts in the gut microbiota due to gastric bypass reduce host weight and adiposity. Sci Transl Med. 2013; 5(178): 178ra41, doi: 10.1126/scitranslmed.3005687, indexed in Pubmed: 23536013

43. Patti ME, Houten S, Bianco A, et al. Serum bile acids are higher in humans with prior gastric bypass: potential contribution to improved glucose and lipid metabolism. Obesity (Silver Spring). 2009; 17(9): 1671-1677, doi: 10.1038/oby.2009.102, indexed in Pubmed: 19360006 
44. van Meijeren J, Timmer I, Brandts $\mathrm{H}$, et al. Evaluation of carbohydrate restriction as primary treatment for post-gastric bypass hypoglycemia. Surg Obes Relat Dis. 2017; 13(3): 404-410 doi: 10.1016/j.soard.2016.11.004, indexed in Pubmed: 10.1016/j. soard.2016.11.004.

45. Bantle JP, Ikramuddin S, Kellogg T, et al. Hyperinsulinemic hypoglycemia developing late after gastric bypass. Obes Surg. 2007; 17(5) 592-594, doi: 10.1007/s11695-007-9102-6.

46. Valderas JP, Ahuad J, Rubio L, et al. Acarbose improves hypoglycaemia following gastric bypass surgery without increasing glucagon-like peptide 1 levels. Obes Surg. 2011; 22(4): 582-586, doi: 10.1007/s11695-011-0581-0, indexed in Pubmed: 22161170.

47. Moreira RO, Moreira RBM, Machado NAM, et al. Post-prandial hypoglycemia after bariatric surgery: pharmacological treatment with verapamil and acarbose. Obes Surg. 2008; 18(12): 1618-1621, doi: 10.1007/s11695-008-9569-9, indexed in Pubmed: 18566871
48. Semple CG, Thomson JA, Beastall GH, et al. Oral verapamil does not affect glucose tolerance in non-diabetics. Br J Clin Pharmacol. 2012; 15(5): 570-571, doi: 10.1111/j.1365-2125.1983.tb02094.x, indexed in Pubmed: 6860534.

49. Myint KS, Greenfield JR, Farooqi IS, et al. Prolonged successful therapy for hyperinsulinaemic hypoglycaemia after gastric bypass: the pathophysiological role of GLP1 and its response to a somatostatin analogue. Eur J Endocrinol. 2012; 166(5): 951-955, doi: 10.1530/eje11-1065, indexed in Pubmed: 22408121.

50. Spanakis E, Gragnoli C. Successful medical management of status post-Roux-en-Y-gastric-bypass hyperinsulinemic hypoglycemia. Obes Surg. 2009; 19(9): 1333-1334, doi: 10.1007/s11695-009-9888-5, indexed in Pubmed: 19551453.

51. Gonzalez-Gonzalez A, Delgado M, Fraga-Fuentes M. Use of diazoxide in management of severe postprandial hypoglycemia in patient after Roux-en-Y gastric bypass. Surg Obes Relat Dis. 2013; 9(1): e18-e19, doi: 10.1016/j.soard.2011.05.010, indexed in Pubmed: 21723202. 